\title{
Partial deletion 21: case report with biochemical studies and review.
}

\author{
NANCY J CARPENTER, JARY S MAYES, BURHAN SAY, AND \\ DON P WILSON \\ H Allen Chapman Research Institute of Medical Genetics, Children's Medical Center, Tulsa, Oklahoma, USA
}

SUMMARY An unbalanced translocation of a portion of the long arm of chromosome 21 to the short arm of chromosome 4 resulted in a partial deletion of chromosome 21 (pter $\rightarrow q 21.05)$ and in the loss of the telomere of $4 \mathrm{p}$. The phenotype of the child included asymmetrical facies, microcephaly, short stature, hypotonia, and psychomotor retardation associated with frequent infections. Normal SOD-1 activity in red blood cells and fibroblasts and normal cystathionine $\beta$ synthase activity in fibroblasts suggest that these gene loci are distal to $21 \mathrm{q} 21 \cdot 05$.

Most structural abnormalities of chromosome 21 are rings resulting from terminal deletions, although unbalanced translocations and interstitial deletions of portions of the long arm have occasionally been reported. ${ }^{1}$ We describe a child with an unbalanced translocation involving chromosomes 4 and 21 resulting in deletion $21 \mathrm{pter} \rightarrow \mathrm{q} 21.05$, who exhibited some of the features reported in other cases of proximal monosomy $21 \mathrm{q}$.

\section{Case report}

The proband, a female, was the third child born to a mother and father who were 33 and 32 years old, respectively. The infant was born at term by breech delivery after a rapid labour.

The mother's previous two pregnancies resulted in two healthy daughters, now 14 and six years old. There is no family history of congenital malformations, mental retardation, or multiple spontaneous abortions.

At birth, the patient's weight was $2155 \mathrm{~g}$, length $48 \mathrm{~cm}$, and head circumference $32.5 \mathrm{~cm}$. Apgar scores were 7,7 , and 6 at one, five, and 10 minutes. She had mild respiratory distress and was hypotonic. An intermittent grade I/IV short systolic murmur was present, thought to be due to a persistent ductus arteriosus. The ECG was normal except for sinus bradycardia. A right subependymal cerebral haemorrhage resolved by the fifth day of

Received for publication 12 August 1986

Accepted for publication 22 September 1986. life. A brain scan showed no dilatation of the ventricles, but an EEG showed episodic focat dysrhythmia of the left temporal area. Visuat evoked potential studies showed P100 values typicad of an infant of 36 to 37 weeks' gestational age. She

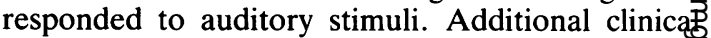
findings included a hoarse cry, small facies with micrognathia, low set ears, and long toes with a long midline crease in each foot. She was discharged from hospital at 11 days of age.

An EEG at 40 days of age showed suppression of activity in the right posterior hemisphere and rhythmic slow activity in the right frontal area. The child had recurrent, mostly viral, infections. At nine months tubes were inserted in both tympaniळ membranes. Serum immunoglobulin levels at $2 \mathscr{C}^{2}$ months were normal.

At 34 months of age the child's weight was 7.64 $\mathrm{kg}$, height $81.2 \mathrm{~cm}$, and head circumference 42 sonn all below the 3 rd centile for age. She was unable to crawl or walk and she had no speech but was ableq use sign language to a limited extent. She had facia asymmetry with the left side being smaller than the right and had a tendency to tilt her head to the lefto Other facial features included a prominent fore $\varrho$ head, horizontal palpebral fissures, high nasa $\vec{E}$ bridge, micrognathia, and low set, posteriorly rotated $B$ ears with prominent antihelices (fig 1). No hear murmurs could be detected. Her hands were slendep with ulnar deviation of the second and third fingers: bilaterally. Her feet were narrow with prominent heels. The results of the Developmental Sequence Performance Inventory administered at 49 months of age were at the 23 month level for gross motoro fine motor, and social/self-help skills and at the $2 \gtrless$ month level for cognitive and language skills.

\section{CYTOGENETIC STUDIES}

Giemsa-trypsin banding of prophase and prometa ô phase chromosomes from the child's cultured blood lymphocytes and skin fibroblasts showed 45 chromoN somes with a single normal chromosome 4 and $\alpha_{\alpha}$ single normal chromosome 21 . The distal segment of the long arm of the other chromosome 21 was trans? located to the telomeric region of the short arm of the second chromosome 4 (fig 2). The child was therefore monosomic for the short arm, centromere and proximal part of the long arm of chromosome 2 伭 
and for the telomere of chromosome $4 \mathrm{p}$. Her karyotype was $45, \mathrm{XX},-4,-21,+\operatorname{der}(4), \mathrm{t}(4 ; 21)$ (4qter $\rightarrow 4 \mathrm{p} 16 \cdot 3:: 21 \mathrm{q} 21 \cdot 05 \rightarrow 21 \mathrm{qter})$. Fibroblastsfrom the child have been contributed to the NIGMS Human Genetic Mutant Cell Repository (GM 8210). The karyotypes of the parents were normal.

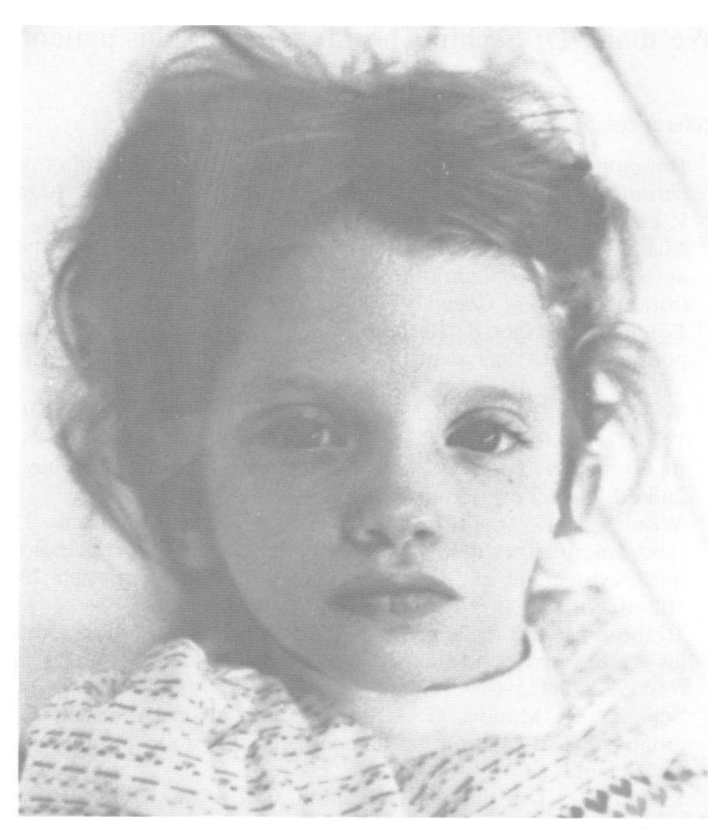

FIG 1 The patient at the age of four years.

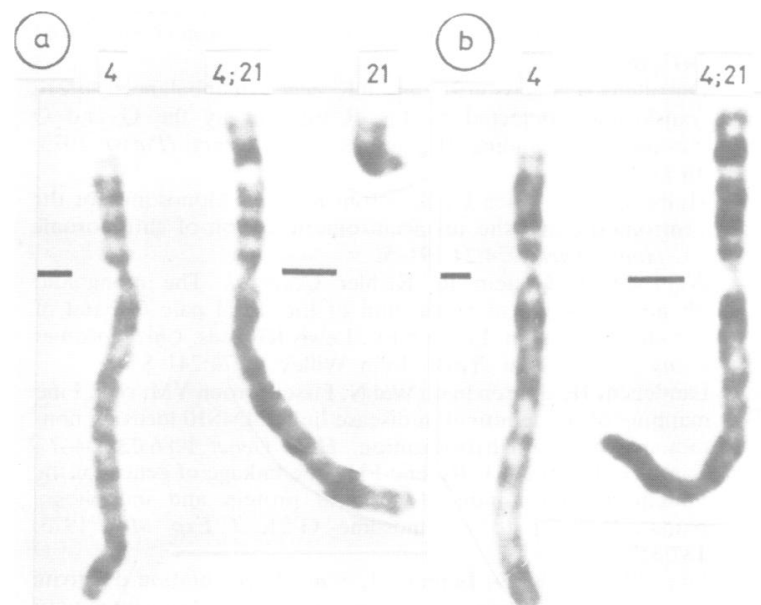

DERMATOGLYPHICS

Dermatoglyphic analysis of the hand showed nine ulnar loops and one whorl. The total finger ridge count (87), atd angle $\left(86^{\circ}\right)$, and the palmar creases were normal. Loops were observed in the fourth interdigital spaces bilaterally.

\section{BIOCHEMICAL STUDIES}

Superoxide dismutase-1 (SOD-1) was assayed by inhibition of the epinephrine autoxidation. ${ }^{2}$ The activity of SOD-1 in red blood cells was $3550 \mathrm{U} / \mathrm{ml}$ of RBC (controls 3080 to 4300 ) and in fibroblasts was $9.0 \mathrm{U} / \mathrm{mg}$ of cell protein (controls 8.3 to 9.9 ).

Cystathionine $\beta$ synthase (CBS) was assayed by Dr Jan Kraus, Yale University. Activity was 25 $\mathrm{mU} / \mathrm{mg}$ of cell protein which is in the normal range for fibroblasts (10 to $30 \mathrm{mU} / \mathrm{ml}$ ).

\section{ENDOCRINE STUDIES}

Standard provocative stimulation tests for growth hormone were conducted using arginine hydrochloride and glucagon. Quantitative levels of growth hormone were normal with a peak response of $14 \mathrm{ng} / \mathrm{dl}$. Somatomedin $\mathrm{C}$ was $0.75 \mathrm{U} / \mathrm{ml}$ (controls 0.14 to $1.44 \mathrm{U} / \mathrm{ml}$ ). Cortisol and thyroid function were normal.

\section{Discussion}

Lejeune $e t a l^{3}$ were the first to report a partial monosomy of a $\mathrm{G}$ group chromosome in an infant mosaic for a ring $(G)$. These investigators considered this case the countertype to Down's syndrome and,

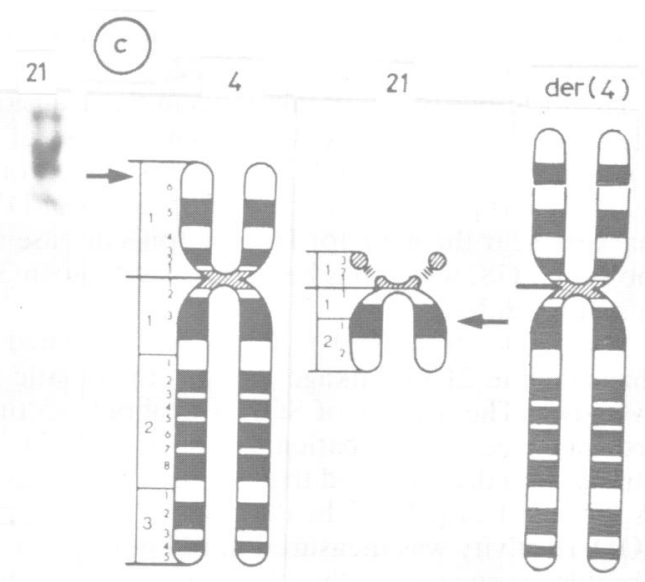

FIG $2(a, b)$ Partial karyotype of the patient with normal chromosomes 4 and 21 and derivative chromosome 4. (c) Diagrammatic illustration of the chromosome rearrangement $t(4 ; 21)(p 16 \cdot 3 ; q 21 \cdot 05)$. Breakpoints are indicated by the arrows. 
as other cases were reported with similar clinical findings, the term 'antimongolism' was used. Warren and Rimoin ${ }^{4}$ divided the $G$ deletion syndromes into two categories, $G$ deletion syndrome I later becoming identified as partial deletion of chromosome 21. Downward slanting palpebral fissures, a broad nasal bridge, microcephaly, significant growth retardation, hypertonia, and psychomotor and mental retardation are features of this syndrome. ${ }^{5}$ Complete monosomy 21 is rare but has been reported to include cleft lip or palate or both and multiple skeletal deformities with congenital contractures, in addition to the previous findings. ${ }^{6}$

The first observation of partial monosomy 21 involving the proximal $\mathrm{q}$ arm was reported by Rethoré et al. ${ }^{f}$ Other cases have since been described resulting from familial or de novo unbalanced translocations of chromosome 21 distal to band q21 onto other autosomes. ${ }^{8-12}$ Reported clinical findings included horizontal palpebral fissures, high forehead, aplastic nasal bridge, skeletal malformations, bone fragility, and mental retardation (IQ below 50). Some differences among the patients are expected, since the breakpoints in $21 \mathrm{q}$ probably differ in each case and the partial deletion of the other autosomes may influence the phenotype.

Our patient does not display the downward slanting palpebral fissures or the joint contractures found in the 21 deletion or monosomy 21 syndromes. She most closely resembles the patient reported by Schmidt $e t$ al $^{8}$ and later by Wahrman $e t$ $a l,{ }^{13}$ who also had the breakpoint approximately in the centre of band 21q21, although this patient had normal growth. In the other cases of proximal monosomy $21 \mathrm{q}$, either the breakpoint is difficult to ascertain from the photographs available or it is located more distally in band 21q22.

The locations of the breakpoints in this translocation make the present case particularly useful for regional localisation of DNA probes on chromosome 21 and possibly for the identification of DNA markers near the gene for Huntington's disease and the probe $\mathrm{G} 8$, which has been mapped to $4 \mathrm{p} 16 \cdot 3$ by in situ hybridisation. ${ }^{14}$

The gene for SOD-1 has been assigned to chromosome 21 by linkage analysis in somatic cell hybrids. ${ }^{15}$ The activity of SOD-1 is about 1.5 times greater in cells from patients with trisomy $21 . .^{16}$ Studies initially indicated that the gene was localised in sub-band $21 \mathrm{q} 22 \cdot 1 .{ }^{18}$ In the present case, normal SOD-1 activity was measured in red blood cells and fibroblasts, suggesting that the gene is located distal to $21 \mathrm{q} 21 \cdot 05$.

The gene for CBS has been assigned to chromosome 21 by somatic cell hybridisation ${ }^{19}$ and the activity of this enzyme is increased by about $50 \%$ in

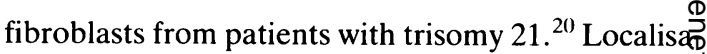
tion of the CBS gene has been suggested to bet between $21 \mathrm{q} 21$ and $21 \mathrm{q} 22 \cdot 1$ by dosage effects partial duplications of chromosome 21 in somatio cell hybrids ${ }^{20}$ and to be in $21 \mathrm{q} 22$ by in sit hybridisation. ${ }^{21}$ Normal activity of CBS in fibro blasts from the proband suggests that the gene foo this enzyme is located distal to $21 \mathrm{q} 21 \cdot 05$.

We thank Dr Sechin Cho for referring this patiente

\section{References}

1 Borgaonkar DS.Chromosome variations in man. A catalog chromosomal variants and anomalies. 4th ed. New York: Alap R Liss, 1984.

2 Misra HP, Fridovich I. The role of superoxide anion in the autoxidation of epinephrine and a simple assay for superoxide dismutase. J Biol Chem 1972;247:3170-5.

${ }^{3}$ Lejeune J, Berger R, Rethoré MO, et al. Monosomie partielle pour un petit acrocentrique. $C R$ Acad Sci [D] (Paris 1964;259:4187-90.

4 Warren RJ, Rimoin DL. The G deletion syndromes. J Pediatr 1970;77:658-63.

de Grouchy J, Turleau C. Clinical atlas of human chromosomes 2nd ed. New York: John Wiley, 1984.

6 Wisniewski K, Dambska M, Jenkins EC, et al. Monosomy $2 \overrightarrow{\mathrm{Q}}$ syndrome: further delineation including clinical, neuropathological, cytogenetic and biochemical studies. Clin Genet 1983.23102-10.

7 Rethoré MO, Dutrillaux B, Baheux G, et al. Monosomie les regions juxtacentromeriques d'un chromosome 21. Exp 太్ Res 1972;70:455-6.

${ }^{8}$ Schmidt R, Mundel G, Rosenblatt M, et al. Apparent $\cdot$ monosomy, G-deletion, and incomplete Down's syndrome in single family. J Med Genet 1972;9:457-61.

${ }^{4}$ Laurent C, Dutrillaux B, Biemont CL. et al. Translocation $\mathrm{t}(14 \mathrm{q}-; 21 \mathrm{q}+)$ chez le pere. Trisomie 14 et monosomie $2 \mathrm{P}$ partielles chez la fille. Ann Genet (Paris) 1973;16:281-4.

10 Rethoré MO, Dutrillaux B, Lejeune J. Translocation $46, X X, t(15 ; 21)(q 13 ; q 221)$ chez la mère de deux enfants atteints de trisomie 15 et de monosomie 21 partielles. Ann Genet (Paris 1973; 16:271-5

"Dutrillaux B, Jonasson J, Lauren K, et al. An unbalanced 4q/21 क्षु translocation detected by the $R$ but not by the $G$ and 8 chromosome banding techniques. Ann Genet (Paris) 1973: 16:11-6.

12 Holbeck S, Freidrich U, Brostrom K, et al. Monosomy for the centrometric and the juxtacentromeric region of chromosome 21. Hum Genet 1974:24:191-5.

13 Wahrman J, Goitein R, Richler C, et al. The mongoloid phenotype is duc to triplication of the distal pale $G$ band of chromosome 21. In: Pearson PL, Lewis KR, eds. Chromosomes today. Vol 5. New York: John Willey, 1974:241-8.

14 Landegent JE, Jansen in de Wal N, Fisser-Groen YM, et al. Fine mapping of the Huntington disease linked D4S10 locus by non-6 radioactive in situ hybridization. Hum Genet 1986;73:354-7.

15 Tan YH, Tischfield J, Ruddle FH. The linkage of genes for the human interferon-induced antiviral protein and indophenof oxidase-B traits to chromosome G-21. J Exp Med 1973 137:317-30.

16 Sinet PM, Allard D, Lejeune J, et al. Augmentation d'activit@ de la superoxyde dismutase erythrocytaire dans la trisomie pouro le chromosome 21. C R Acad Sci /D] (Paris) 1974;278:3267-70

17 Feaster WW, Kwok LW, Epstein CJ. Dosage effects for superoxide dismutase- 1 in nucleated cells aneuploid for chromosome 21. Am J Hum Genet 197.7;29:563-70. 
${ }^{18}$ Sinet PM, Couturier J, Dutrillaux B, et al. Trisomic 21 et superoxyde dismutase-1 (IPO-A). Tentative de localisation sur le sous-bande 21q21·1. Exp Cell Res 1976;97:47-55.

19 Skovby F, Krassikoff N, Francke U. Assignment of the gene for cystathionine beta-synthase to human chromosome 21 in somatic cell hybrids. Hum Genet 1984;65:291-4.

20) Chadefaux B, Rethoré MO, Raoul O, et al. Cystathionine betasynthase: gene dosage effect in trisomy 21. Biochem Biophys Res Commun 1985;128:40-4.

21 Kraus JP, Williamson CL, Firgaira FA, et al. Cloning and screening with nanogram amounts of immunopurified mRNAs:
cDNA cloning and chromosomal mapping of cystathionine beta-synthase and the beta subunit of propionyl-CoA carboxylase. Proc Natl Acad Sci USA 1986;83:2047-51.

Correspondence and requests for reprints to $\mathrm{Dr}$ Nancy J Carpenter, H Allen Chapman Research Institute of Medical Genetics, Children's Medical Center, 5300 East Skelly Drive, Tulsa, Oklahoma 74135, USA.

\title{
Deletion $15 \mathrm{q} 21 \cdot 1 \rightarrow \mathrm{q} 22 \cdot 1$ resulting from a paternal insertion into chromosome 5
}

\author{
MOH-YING YIP*, MARK SELIKOWITZ†, NEVILLE DON†, \\ ALEX KOVACIC*, S PURVIS-SMITH*, AND P R L LAM-PO-TANG* \\ ${ }^{*}$ Cytogenetics Unit, Prince of Wales Hospital, and + Department of Paediatric Medicine, Prince of Wales \\ Children's Hospital, Sydney, Australia.
}

SUMMARY A 15 month old boy with an interstitial deletion $15 \mathrm{q}$ derived from a paternal insertion $(5 ; 15)(\mathrm{q} 31 \cdot 3 ; \mathrm{q} 21 \cdot 1 \mathrm{q} 22 \cdot 1)$ is described and compared with one other reported case. A beak like nose with hypoplastic nasal alae, a thin upper lip, failure to thrive in infancy with later onset of obesity, and severe mental retardation are features common to both.

Insertions involving three breakpoints are the least common chromosome rearrangements in man. ${ }^{1}$ With banding studies, insertions have been detected between and within chromosomes. We are aware of 21 published reports of interchromosomal insertions. We describe here a case of an interstitial deletion of $15 \mathrm{q} 21 \cdot 1 \rightarrow \mathrm{q} 22 \cdot 1$ derived from a paternal insertion in a 15 month old boy.

\section{Case report}

The proband was the first live born child of healthy, unrelated parents. At his birth, the mother was 25 and the father 30 . There were three previous miscarriages at six, eight, and 12 weeks.

The pregnancy with the proband was complicated by polyhydramnios and decreased fetal movement which developed at 30 weeks. Caesarian section was performed at 35 weeks' gestation for intrauterine growth retardation. The Apgar scores were 8 and 9 at one and five minutes, respectively. The birth weight was $1680 \mathrm{~g}$ (less than the 3 rd centile), head circumference $30.7 \mathrm{~cm}$ (10th centile), and birth length $40 \mathrm{~cm}$ (3rd centile). Dysmorphic features noted at birth were: narrow bifrontal diameter, a patent posterior fontanelle, low temporal hair implantation, and low set ears. The mouth had a thin upper lip and was usually kept open. The nose was beak shaped with poor development of the nasal alae (fig 1a). The hands were held in ulnar deviation and there was bilateral clinodactyly of the fifth fingers and simian creases. Dermal ridge whorl patterns were present on all 10 fingers. Creases were decreased around the elbows and knees which, however, had a full range of movement (fig 1b). The testes were bilaterally undescended with an underdeveloped scrotum. Bilateral inguinal herniae were present and the penis was of normal size but hooded with coronal hypospadias and chordee.

There was hypotonia and poor feeding. He had occasional apnoeic episodes during the neonatal period. A chest $x$ ray showed a raised anteromedial portion of the right hemidiaphragm which was inserted high on the posterior surface of the sternum. $X$ ray of the spine showed that the vertebral bodies had a square outline and reduction of interpedicular distances in the lumbar region.

From the age of six months the patient has gained weight rapidly despite dietary joule restriction. At present, at the age of 15 months, his weight is on the 90th centile and his length on the 10th centile. His psychomotor development corresponds to a six month level. He has developed a mild degree of scoliosis and strabismus associated with myopia. 